\title{
Recent Advances in the Treatment of Scedosporiosis and Fusariosis
}

\author{
Matthew W. McCarthy ${ }^{1, *,+}$, Aspasia Katragkou ${ }^{2, \dagger}{ }^{+}$Elias Iosifidis ${ }^{3,+}{ }^{(1)}$, Emmanuel Roilides ${ }^{3,+}$ (1) \\ and Thomas J. Walsh ${ }^{4,+}$ \\ 1 Division of General Internal Medicine, Weill Cornell Medicine of Cornell University, New York, \\ NY 10065, USA \\ 2 Department of Pediatrics, Division of Pediatric Infectious Diseases, Nationwide Children's Hospital and The \\ Ohio State University, Columbus, OH 43205, USA; Aspasia.Katragkou@nationwidechildrens.org \\ 3 Infectious Diseases Section, 3rd Department of Pediatrics, Faculty of Medicine, Aristotle University School \\ of Health Sciences, 54642 Thessaloniki, Greece; iosifidish@gmail.com (E.I.); roilides@med.auth.gr (E.R.) \\ 4 Transplantation-Oncology Infectious Diseases Program, Departments of Pediatrics, \\ and Microbiology \& Immunology, Weill Cornell Medicine, New York, NY 10065, USA; \\ thw2003@med.cornell.edu \\ * Correspondence: mwm9004@med.cornell.edu; Tel.: +1-212-746-4471 \\ + These authors contributed equally to this manuscript.
}

Received: 26 April 2018; Accepted: 16 June 2018; Published: 18 June 2018

\begin{abstract}
Species of Scedosporium and Fusarium are considered emerging opportunistic pathogens, causing invasive fungal diseases in humans that are known as scedosporiosis and fusariosis, respectively. These mold infections typically affect patients with immune impairment; however, cases have been reported in otherwise healthy individuals. Clinical manifestations vary considerably, ranging from isolated superficial infection to deep-seated invasive infection-affecting multiple organs - which is often lethal. While there have been a number of advances in the detection of these infections, including the use of polymerase chain reaction (PCR) and matrix-assisted laser desorption ionization/time-of-flight mass spectrometry (MALDI-TOF MS), diagnosis is often delayed, leading to substantial morbidity and mortality. Although the optimal therapy is controversial, there have also been notable advances in the treatment of these diseases, which often depend on a combination of antifungal therapy, reversal of immunosuppression, and in some cases, surgical resection. In this paper, we review these advances and examine how the management of scedosporiosis and fusariosis may change in the near future.
\end{abstract}

Keywords: fusariosis; scedosporiosis; isavuconazole; voriconazole; MALDI-TOF

\section{Introduction}

The past few decades have witnessed a remarkable increase in the prevalence and severity of invasive fungal infections (IFI) in children and adults with immune impairment, including patients with hematologic malignancies, stem cell and solid organ transplantations, and primary and acquired immunodeficiencies and preterm neonates [1-3]. The majority of these infections are due to Candida spp. and Aspergillus spp., while less common fungal pathogens, such as mucormycetes, Scedosporium spp., and Fusarium spp. are reported with increasing frequency [4,5]. Diagnostic and therapeutic options against IFI have evolved considerably over the past several years, and in this paper, we will review how these advances affect the management of scedosporiosis and fusariosis in children and adults. 


\section{Scedosporiosis}

\subsection{Diagnosis}

The timely diagnosis of mycotic disease is an enduring challenge in clinical practice. A diagnosis of Scedosporium spp. usually relies on the detection of fungi from clinical samples by direct microscopic examination or histological analysis of the clinical specimen and culture on appropriate culture media [6]. However, it may be difficult to distinguish Scedosporium spp. from species of Fusarium or Aspergillus, as all of them present dichotomous branching, hyaline hyphae, and regular hyphal septation [4,7]. Given this difficulty, newer approaches have been pursued, including non-culture-based molecular methods that utilize nucleic acid sequencing and mass spectroscopy.

Nucleotide sequence-based analysis is the current gold standard for fungal identification; rDNA internal transcribed spacer (ITS) sequencing appropriately identifies the main species in Scedosporium, but the partial $\beta$-tubulin gene $(B T 2)$ is required to differentiate closely related species $[8,9]$. Matrix-assisted laser desorption ionization/time-of-flight mass spectrometry (MALDI-TOF MS) has become available for the first-line identification of filamentous fungi, as its accuracy is comparable to that of DNA sequencing, but it is not routinely available at many medical centers [10].

Polymerase chain reaction (PCR)/electrospray ionization time-of-flight mass spectrometry (ESI-TOF-MS) combines 16 PCR assays using broad-range primers targeting nuclear or mitochondrial genes and T2 magnetic resonance (T2MR), which enables rapid determination of molecular weight and base composition in the amplicons after electrospray ionization and chromatographic separation [11-13]. This information may be compared to a database to identify fungal species, including Scedosporium, without the need for purification or extraction. However, this platform is expensive and is not routinely used at most centers; moreover, the database of filamentous fungi is relatively small, and the process of specimen preparation may be cumbersome [14-16]. These platforms highlight novel strategies to hasten the identification of Scedosporium spp., as a delay in diagnosis is often associated with substandard treatment and poor outcomes.

\subsection{Clinical Manifestations}

Species of the pathogenic mold Scedosporium, including Lomentospora prolificans (formerly S. prolificans), cause a wide range of clinical manifestations in humans from superficial infection to severe invasive disease, as well as colonization of the respiratory tract and allergic reactions [6,17]. Scedosporiosis is classically associated with hematological malignancies (HM), although patients with other forms of immune impairment may also contract the disease [18]. Given the variety of symptoms, clinicians should have a high index of suspicion in susceptible patients. Individuals suffering from near-drowning events in water are also at risk of disease, which may be associated with central nervous system (CNS) involvement [19]. Species of Scedosporium, including S. boydii, S. apiospermum, and S. aurantiacum are among the most commonly recovered molds from respiratory secretions of patients with chronic pulmonary diseases such as cystic fibrosis (CF) and may lead to invasive disease $[4,7,20,21]$.

\subsection{Treatment}

There are three major classes of antifungal agents approved for use in humans: (1) triazoles (fluconazole, voriconazole, isavuconazole, itracontazole); (2) polyenes (various formulations of amphotericin B); and (3) echinocandins (casprofungin, micafungin, anidulafungin) [22-27]. The triazoles and polyenes have varying levels of activity against species of Scedosporium, with the azoles (such as itraconazole and voriconazole) typically having the lowest mean inhibitory concentration (MIC) among the antifungal drugs [28]. Scedosporium species are typically resistant to polyenes, as well as to fluconazole and demonstrate reduced susceptibility to echinocandins $[29,30]$. The high degrees of intrinsic antifungal resistance among species of Scedosporium make these infections difficult to manage 
and susceptibility testing of isolates from patients with scedosporiosis is highly recommended [21,31]. Reversal of immunosuppression is often crucial for successful management of infection [19].

Although the optimal choice and duration of therapy for scedosporiosis is controversial and may depend on the immune status of the patient, a large retrospective study provides support for the use of voriconazole [32]. In that study by Troke and colleagues, the most common underlying conditions were solid organ transplant (SOT, 22\%), hematologic malignancy (HM, 21\%), and trauma or surgery (15\%) [29]. Two-thirds of patients with S. apiospermum infection had successful responses. Patients with malignancy and hematopoietic cell transplant (HSCT) recipients had the worst outcomes [29].

Most international guidelines recommend voriconazole as first-line therapy; however, antifungal combination therapy (ACT) has emerged as a promising option, because therapeutic effect can be achieved at lower concentrations thereby reducing toxic side effects, improving safety and tolerability, and shortening the therapeutic effect while potentially preventing treatment failure [33-36]. The combination of voriconazole with a polyene or an echinocandin has shown synergistic effects against both S. apiospermum and L. prolificans; however, these combinations have demonstrated variable outcome in the treatment of these infections in humans [18,37]. Combinations of three antifungal agents (voriconazole plus a polyene plus an echinocandin) have been tested against $L$. prolificans and showed synergy in vitro, but the data in humans with scedosporiosis is exceedingly limited.

In March 2015, the FDA approved the extended-spectrum triazole isavuconazole for the treatment of invasive aspergillosis and mucormycosis [38,39]. The advantages of this new antifungal drug include the availability of a water-soluble intravenous formulation, excellent bioavailability of the oral formulation, and predictable pharmacokinetics in adults [40,41]. Although this agent has not been approved for the treatment of scedosporiosis, in vitro data suggests that it may have good activity [42].

Guinea and collaborators examined the activity of isavuconazole against more than 1000 opportunistic fungi collected from 1986 to 2007, including 22 isolated of Scedosporium spp. [43]. The two species of Scedosporium tested (S. prolificans and S. apiospermum) showed marked differences in susceptibility: isavuconazole showed good activity against Scedosporium apiospermum, with a $\mathrm{MIC}_{90}$ very similar to those for Aspergillus spp., whereas S. prolificans (L. prolificans) was relatively resistant. Subsequent work by Pfaller and colleagues has reinforced this finding [44]. Indeed, isavuconazole demonstrates broad-spectrum activity against a global collection of opportunistic fungi; however, clinical experience with isavuconazole to treat scedosporiosis is limited, and its use is not routinely recommended.

The novel compound F901318 represents a new class of antifungal drug called the orotomides, which inhibits dihydroorotate dehydrogenase, a key enzyme in pyrimidine biosynthesis [45]. This drug has been evaluated for activity against 50 clinical Scedosporium and Lomentospora isolates [27]. F901318 displayed activity against all isolates S. apiospermum, S. boydii, and S. aurantiacum, with the MIC decrease ranging from 0.125 to $0.5 \mathrm{mg} / \mathrm{L}$. Similarly, Wiederhold and collaborators had similar results with F901318 against S. apiospermum, S. aurantiacum, S. dehoogii, and S. boydii, with the MIC ranging from $\leq 0.008$ to 0.25 [46]. Clinical trials are currently underway.

\section{Fusariosis}

\subsection{Diagnosis}

Although diagnosis may be suspected based on clinical phenomenon in high-risk patients, such as characteristic skin lesions in patients with acute myelogenous leukemia (AML), confirmatory diagnosis of fusariosis by histopathology and culture is strongly recommended by the European Confederation of Medical Mycology and the European Society of Clinical Microbiology and Infectious Diseases (ECMM/ESCMID) guidelines [47,48]. However, given the time and labor associated with these endeavors, other methods have been pursued.

Immunohistochemistry uses antibodies directed at cell antigens to identify fungal organisms visualized in situ. However, this approach is not widely used. Recently, DNA-based assays have 
emerged as a promising new approach to diagnosing fusariosis. A PCR platform based on the intergenic spacer (IGS) region has been developed for different Fusarium species that can also distinguish clinical species complexes, such as Fusarium equiseti and F. sporotrichioides [49]. A fluorescent PCR fragment length analysis based on the internally transcribed spacer 2 (ITS2) region is available to distinguish between Aspergillus, Candida, and F. oxysporum, but this method cannot distinguish between the Fusarium spp. that have closely-related ITS amplicons [50-52].

Multi-locus sequence typing (MLST) is currently viewed as the best option for the identification of Fusarium isolates on the species level, and enzyme-linked immunosorbent assay (ELISA) is the preferred method in Fusarium to identify specific mycotoxins [51,53-55]. As noted above, MALDI-TOF MS is a promising new tool for rapid identification and classification of cultured microorganisms based on their protein spectra [56-58]. However, the platform is not widely available and requires the recovery of the organism for processing. We anticipate that in the coming years, this methodology will become the preferred method for identification of fusariosis, especially at tertiary-care and academic medical centers.

\subsection{Clinical Manifestations}

Fusarium species cause a variety of diseases in humans, including superficial skin infections, keratitis, blood stream infections, and life-threatening end organ damage $[59,60]$. Infection may be fatal, as there is often a delay in diagnosis and many organisms exhibit high-levels of resistance to existing antifungal agents [61,62]. Fusarium spp. are a frequent cause of corneal damage and may lead to endophthalmitis [62]. Although onychomycosis as a result of fusariosis usually causes localized infection in immunocompetent patients, it may also represent the portal of entry for disseminated disease in patients with immune impairment $[48,63]$.

Less commonly, Fusarium spp. may cause peritonitis, bloodstream infection, osteomyelitis (often after trauma), arthritis, otitis, sinusitis, and brain abscess [19,48]. As we will discuss below, treatment often involves antifungal therapy in conjunction with surgical resection and reversal of immunosuppression when possible.

\subsection{Treatment}

Fusarium spp. often display high levels of resistance to existing antifungal agents and are some of the more difficult fungi to treat $[62,64,65]$. Data on their in-vitro susceptibility to various antifungal agents indicate variable susceptibility amphotericin B and extended-spectrum triazoles, such as itraconazole, voriconazole, isavuconazole and posaconazole $[51,53,54,66,67]$. For this reason, we typically initiate empirical therapy with an antifungal triazole and a poleyene, such as voriconazole and liposomal amphotericin B, while awaiting antifungal susceptibilities. One notable exception to this approach may be for $F$. solani, which is somewhat more susceptible to amphotericin B but less susceptible to voriconazole than other species, such as F. oxysporum [68,69]. However, the optimal treatment for disseminated fusariosis has not been established. While polyenes and itraconazole have been associated with some success, voriconazole is the only agent with an indication for treating refractory fusariosis in the United States [19].

Essential for successful therapeutic outcome is the restoration of innate host defenses, particularly with recovery from neutropenia. GCSF may accelerate recovery from neutropenia. Granulocyte transfusions from GCSF-mobilized donors may stabilize infection until recovery from neutropenia in persistently neutropenic patients with hematological malignancies or in those with aplastic anemia.

There are currently a number of novel antifungal agents in the pre-clinical pipeline that may have activity against human fusariosis [70]. These include E1210, a novel isoxazolyl bis-pyridine wall-active antifungal compound (discovered by the Eisai Company in Japan) that inhibits an early step in the GPI-dependent anchoring cell wall proteins and has in vitro activity against Fusarium spp. [71-73]. The pyrimidine salvage pathway offers another potential target (as noted above). F901318 is highly active in vitro against triazole-resistant mold pathogens, including Scedosporium and Fusarium species $[70,74]$. Genetic and biochemical analyses indicate that hemofungin may serve as yet another 
potential treatment option, as it inhibits ferrochelatase-the last enzyme in the heme biosynthetic pathway - and inhibits in vitro growth of pathogenic Fusarium species [70]. We are encouraged by this early work and are eager to see if these promising results may have utility in humans.

\section{Strategies for Augmentation of Host Defenses against Scedosporiosis and Fusariosis}

Host defenses against filamentous non-Aspergillus filamentous fungi are less well understood than those against aspergilli. However, limited data with Fusarium spp. and Scedosporium spp. show certain similarities in pathogenesis and host defenses with Aspergillus fumigatus, with which most studies have been performed.

The predominant line of host defenses against filamentous fungi is circulating polymorphonuclear (PMNs) and mononuclear leukocytes (MNCs), as well as monocyte-derived macrophages (MDMs) [75]. MDMs in the lungs and elsewhere phagocytize and destroy spores of difficult-to-treat filamentous fungi, such as S. apiospermun and S. prolificans [76,77], comparably to A. fumigatus. If the immune response of the host is compromised, spores can germinate to hyphae and invade to adjacent tissues. PMNs are the main immune cells causing damage to hyphae using oxygen-dependent $\left(\mathrm{O}_{2}{ }^{-}, \mathrm{H}_{2} \mathrm{O}_{2}\right.$, hypohalides, and chloramines) and oxygen-independent (cationic peptides such as defensins and cathelicidins) mechanisms [78]. Phagocytes are capable of exhibiting sufficient oxidative burst to control S. prolificans [77].

A variety of growth factors, cytokines, and chemokines play an important role in the interface of innate and adaptive immunities against filamentous fungal infections [79]. However, very little is known about how fungal elements are recognized by macrophages and how the signal is transduced to the nucleus for gene expression and release of cytokines in response to Fusarium or Scedosporium spp. Of note, S. prolificans has been shown to induce significantly more TNF- $\alpha$ and IL-6 release by human MNCs as compared to Aspergillus spp., which could be associated with the virulence of the specific fungus [80]. Differences in immune response and damage of different genera of filamentous fungi and indeed of different species of Fusarium and Scedosporium are likely linked to the frequency and severity of infections by some of these fungi.

A number of studies have assessed the immunomodulatory utility of cytokines in confronting fungal pathogens. Th1- and Th17-type cytokines have exhibited certain enhancing activities on antifungal phagocytic responses. For example, IL-15 increased interleukin-8 (IL-8) release from PMNs challenged by F. solani hyphae, but not by F. oxysporum hyphae. In contrast, the release of TNF- $\alpha$ was not affected by the use of IL-15 [81]. Similarly, IL-15 increased IL-8 release from PMNs challenged by S. prolificans, whereas release of TNF- $\alpha$ was not affected. In addition, the presence of IL-15 significantly enhanced PMN-induced hyphal damage and oxidative respiratory burst of S. prolificans but not S. apiospermum. This inability of IL-15 to exhibit enhanced damage of S. apiospermum hyphae is in concordance with this fungus' greatest intrinsic virulence in humans. IL-15 may have species-specific enhancing effects on antifungal activities of PMNs against Scedosporium spp. and Fusarium spp. [81].

Among other cytokines studied that enhance PMN antifungal activity against Scedosporium spp. are interferon- $\gamma$ (IFN- $\gamma$ ) and granulocyte-macrophage colony-stimulation factor (GM-CSF) [82]. These cytokines induce the Th1 response, which favors resistance to fungal disease, regulates the gene expression of NADPH oxidase subunits at the transcriptional level, and potentiates the synthesis of antimicrobial peptides in macrophages [83]. GM-CSF acts on early as well as on late stages of haematopoiesis and increases the number of cells of the macrophage-monocyte system. It has been found to enhance phagocytosis, oxidative burst, increase the number and membrane binding of several classes of surface receptors on PMNs, and inhibit PMN apoptosis [84,85]. Treatment of PMNs with the combination of IFN- $\gamma$ and GM-CSF had broader effects on Scedosporium spp., enhancing PMN functions including oxidative burst in response to S. apiospermum hyphae [82].

Antifungal agents may also have differential immunomodulatory effects against Fusarium and Scedosporium spp. In vitro studies have shown that MDM activity against Fusarium spores [86], oxidative antifungal activities of human MNCs and PMNs against F. solani hyphae [87], and PMN activity against S. prolificans and S. apiospermum [88] can be modulated by the presence of different 
amphotericin B formulations. Similarly, triazoles have caused significant additive increase in PMN hyphal damage of S. prolificans and S. apiospermum [89]. Regardless of the mechanisms behind these collaborative effects, these findings support the concomitant administration of antifungals and PMN transfusions to persistently neutropenic patients with invasive fusariosis or scedosporiosis.

No animal model studies have reported on the effects of cytokines, such as granulocyte colony stimulating factor (G-CSF), on the outcome of experimental fusariosis to date. Ortoneda et al., in an immunosuppressed murine model of invasive infection by $S$. prolificans, demonstrated a modest efficacy of liposomal amphotericin B (LAMB) at $10 \mathrm{mg} / \mathrm{kg} /$ day combined with G-CSF [90]. Subsequent studies showed that LAMB at very high doses $(40 \mathrm{mg} / \mathrm{kg} /$ day $)$ combined with G-CSF did not significantly improve survival [91]. Interestingly, the administration of G-CSF alone was not more effective as compared to the control group [90,91]. In an immunocompetent murine model of disseminated S. prolificans infection, posaconazole and GM-CSF had a combined effect in damaging S. prolificans hyphae. However, when posaconazole and GM-CSF were administered to mice with invasive infection due to $S$. prolificans, they had selective beneficial effects on the burdens in certain organs but offered no additional benefit to survival [92].

The principal therapy in fusariosis is early aggressive antifungal therapy. Immunomodulation with G-CSF or GM-CSF potentially combined with IFN- $\gamma$ can be adjuvant therapeutic strategies together with source control. Over the last decades, efforts to reconstitute host defenses with granulocyte transfusion therapy have increased after the advances of the availability of recombinant hematopoietic growth factors and modern transfusion practices. In severely neutropenic patients suffering from fusariosis, treatment with G-CSF or GM-CSF and granulocyte transfusions may be considered [93-97]. The beneficial effect of the granulocyte transfusions seems to be enhanced when they are collected after stimulation of donors with G-CSF and dexamethazone and are administered to patients with good performance status, as well as early during neutropenia and soon after the onset of fungal infection [98]. In a systematic review of 23 cases with invasive fusariosis, including eight patients aged less than 18 years, granulocyte transfusion using traditional collection protocols failed to augment the efficacy of appropriate antifungal treatment. In contrast, in a case series of 11 invasive fusariosis from a single center, remarkably high response and survival rates were found when antifungal agents were combined with granulocyte transfusions, which were collected using a specific donor collection protocol (donors were stimulated by G-CSF and dexamethasone).

The clinical evidence on the role of immunomodulation on the host response against scedosporiosis is limited, involving mainly haematopoietic growth factors (G-CSF or GM-CSF) and IFN- $\gamma$ [99]. Of note, of 39 cases reported with disseminated Scedosporium spp. infection, a favorable outcome was reported only in four of them [100]. In these four cases, the positive outcome was attributed to the immunomodulatory factors administered in addition to antifungal drugs, whereas the true role of antifungals was difficult to establish $[101,102]$. Without doubt, the outcome of antifungal drug therapy alone in scedosporiosis is poor with high overall mortality. A crucial point in the management of this difficult-to-treat infection is immune function reconstitution. Characteristically, only 2 out of 16 patients infected with S. prolificans survived, and their survival coincided with hematologic recovery [103]. Similarly, in another review, disseminated S. prolificans infection was fatal in all neutropenic patients [104].

\section{Management of Scedosporium and Fusarium Infections in Children}

Pediatric pharmacokinetic, safety, and efficacy data are sparser than those in adult patients. As a consequence, the pace of guideline development for pediatric patients has been much slower than that for adults, and indeed, dedicated guidelines for treating infants and children with IFI do not exist. Extrapolating adult recommendations to pediatric practice should be done cautiously, as differences pertaining to epidemiological factors and pharmacokinetics of many antifungal agents exist between adults and children. 


\subsection{Pediatric Scedosporiosis}

Scedosporium spp. infections in children have been associated with brain abscess formation after near drowning in immunocompetent individuals [19]. These infections are inherently difficult to treat given the delayed diagnosis, the histologic similarities of spedosporium infection with other more frequently encountered filamentous fungi, the cross reactivity of immune reactions with other fungi, and the false negative immune reaction results due to the high genetic variability of Pseudallescheria spp. [105]. The most recent reports with favorable outcomes indicate that voriconazole may be an effective antifungal agent, as salvage treatment options, parenteral administration of terbinafine and voriconazole in addition to intraventricular caspofungin, and neurosurgical interventions have been used but with mixed results [106]. Among adjunctive therapeutic modalities, the administration of certain cytokines interferon (IFN- $\gamma$ ) and granulocyte-macrophage colony-stimulation factor (GM-CSF), which induce an augmentation of neutrophil antifungal activity against Scedosporium spp., has been proposed [82].

\subsection{Pediatric Fusariosis}

Fusarium spp. infections are between the third and fourth most common cause of IFI in children; F. solani and F. oxysporum species complex are the most commonly implicated in pediatric disease [107-109]. Clinical presentation of Fusarium spp. infections depends on the portal of entry, as well as the host's immune status. In immunocompetent patients, infections are usually superficial (onychomycosis, keratitis, or mycetoma) or limited to a single organ (lungs or paranasal sinuses), whereas in immunosuppressed hosts, such as allogeneic hematopoietic stem cell recipients, patients with severe or prolonged neutropenia, or acute leukemia, fusariosis may be invasive and disseminated $[63,110]$.

Given the rarity of these infections, treatment guidelines are not based on randomized controlled clinical trials but on large uncontrolled case series mainly in adult patients [111]. Especially in the pediatric population, treatment of scedosporiosis and fusariosis is challenging, with all-cause mortality in pediatric case series as high as 50\% [108,112]. Evidence-based data for guiding treatment are scant, and usually treatment recommendations are inferred from adult experience. On many occasions, salvage treatment options are required, which include the use of newer antifungal agents and practices aiming to reduce immunosuppression [111,112].

The FungiScope registry, a global fungal infection registry, found 10 children with invasive fusariosis between 2006 and 2015 [113]. All these patients were immunosuppressed and neutropenic, and among these, $80 \%$ received combination therapy with voriconazole and either a lipid formulation of amphotericin B (50\%) or an echinocandin (30\%), and only $20 \%$ received voriconazole monotherapy. Surgery was performed in 30\%, granulocyte transfusion and granulocyte colony stimulating factor (G-CSF) were used in $40 \%$ of the patients each.

A recent literature review of invasive Fusarium infections in immunocompromised children (including five new cases, summarizing 33 cases in total) showed considerable variation in the treatment regimens used: Amphotericin B was used in most cases $(76 \%)$; combination treatment with (amphotericin B and voriconazole; amphotericin B and caspofungin; amphotericin B, fluconazole, and rifampin; amphotericin B and ketoconazole; amphotericin B, 5-FC, and rifampin) was used in 33\%; G-CSF was used in 18\%; granulocyte transfusion in $12 \%$; and surgery was performed in $12 \%$ of the cases [108]. In both of the above studies, a favorable outcome was noted in 50\% of the patients $[108,112]$.

Posaconazole has been recommended as a salvage treatment option for invasive fusariosis in high-risk patients with hematologic malignancies [111]. Data for posaconazole use for fusariosis treatment come from three open label clinical trials [114] and a retrospective single institution analysis [115], which hardly included any children ( $<18$ years of age). The limited use of posaconazole in children could be due to limited experience in patients less than 12 years of age [111,112] (Table 1). Similarly, there is no experience with isavuconazole use in children with fusariosis [116]. The two clinical trials (SECURE and VITAL), which evaluate the use of isavuconazole in the treatment of fungal infections, including rare fungi, enrolled patients who were more than 18 years old. Thus far, they have reported only seven patients with fusariosis treated with isavuconazole, resulting in a $44 \%$ survival rate [117]. 
Table 1. Pediatric doses of systemic antifungal agents.

\begin{tabular}{|c|c|c|c|c|c|}
\hline \multirow{2}{*}{ Agent } & \multicolumn{5}{|c|}{ Daily Dosage Per Age Group } \\
\hline & $>18$ Years & 13-18 Years & 2-12 Years & 1-24 Months & Neonates \\
\hline Amphotericin B deoxycholate & $1-1.5 \mathrm{mg} / \mathrm{kg}$ QD & $1-1.5 \mathrm{mg} / \mathrm{kg} \mathrm{QD}$ & $1-1.5 \mathrm{mg} / \mathrm{kg} \mathrm{QD}$ & $1-1.5 \mathrm{mg} / \mathrm{kg} \mathrm{QD}$ & $1-1.5 \mathrm{mg} / \mathrm{kg}$ QD \\
\hline Liposomal amphotericin B & $3-5 \mathrm{mg} / \mathrm{kg}$ QD & $3-5 \mathrm{mg} / \mathrm{kg}$ QD & $3-5 \mathrm{mg} / \mathrm{kg}$ QD & $3-5 \mathrm{mg} / \mathrm{kg}$ QD & $3-5 \mathrm{mg} / \mathrm{kg}$ QD \\
\hline Amphotericin B lipid complex & $5 \mathrm{mg} / \mathrm{kg}$ QD & $5 \mathrm{mg} / \mathrm{kg}$ QD & $5 \mathrm{mg} / \mathrm{kg}$ QD & $5 \mathrm{mg} / \mathrm{kg} \mathrm{QD}$ & $5 \mathrm{mg} / \mathrm{kg}$ QD \\
\hline $\begin{array}{c}\text { Amphotericin B } \\
\text { colloidal dispersion }\end{array}$ & $3-4 \mathrm{mg} / \mathrm{kg}$ QD & $3-4 \mathrm{mg} / \mathrm{kg}$ QD & $3-4 \mathrm{mg} / \mathrm{kg}$ QD & $3-4 \mathrm{mg} / \mathrm{kg}$ QD & $\mathrm{n} / \mathrm{a}$ \\
\hline Itraconazole IV & $\begin{array}{l}200 \mathrm{mg} \text { BID (for } 2 \text { days), followed } \\
\text { by } 200 \mathrm{mg} \text { QD }\end{array}$ & $\mathrm{n} / \mathrm{a}$ & $\mathrm{n} / \mathrm{a}$ & $\mathrm{n} / \mathrm{a}$ & $\mathrm{n} / \mathrm{a}$ \\
\hline $\begin{array}{c}\text { Itraconazole oral } \\
\text { suspension/capsules* }\end{array}$ & $\begin{array}{c}600 \mathrm{mg} \text { QD (for } 3 \text { days), followed } \\
400 \mathrm{mg} \text { QD }\end{array}$ & $2.5 \mathrm{mg} / \mathrm{kg}$ BID & $2.5 \mathrm{mg} / \mathrm{kg}$ BID & $\mathrm{n} / \mathrm{a}$ & $\mathrm{n} / \mathrm{a}$ \\
\hline Voriconazole IV* & $\begin{array}{c}6 \mathrm{mg} / \mathrm{kg} \text { Q12h on day } 1 \text { then } \\
4 \mathrm{mg} / \mathrm{kg} \text { BID }\end{array}$ & $4 \mathrm{mg} / \mathrm{kg}$ BID & $8 \mathrm{mg} / \mathrm{kg}$ BID & $\mathrm{n} / \mathrm{a}$ & $\mathrm{n} / \mathrm{a}$ \\
\hline $\begin{array}{c}\text { Voriconazole oral } \\
\text { suspension/capsules* }\end{array}$ & $200 \mathrm{mg}$ BID & $200 \mathrm{mg}$ BID & 9 mg /kg BID (max: 350 mg BID) & $\mathrm{n} / \mathrm{a}$ & $\mathrm{n} / \mathrm{a}$ \\
\hline Posaconazole* & 200 mg QID or 400 mg BID & 200 mg QID or 400 mg BID & $\mathrm{n} / \mathrm{a}$ & $\mathrm{n} / \mathrm{a}$ & $\mathrm{n} / \mathrm{a}$ \\
\hline Caspofungin & $50 \mathrm{mg} /$ day (day 1: $70 \mathrm{mg}$ ) & $50 \mathrm{mg} / \mathrm{m}^{2}$ (day 1: 70, $\max 70 \mathrm{mg}$ ) & $50 \mathrm{mg} / \mathrm{m}^{2}$ (day 1: 70, $\max 70 \mathrm{mg}$ ) & $\begin{array}{c}50 \mathrm{mg} / \mathrm{m}^{2} \text { (day 1: } 70 \\
\max 70 \mathrm{mg})\end{array}$ & $25 \mathrm{mg} / \mathrm{m}^{2}$ \\
\hline Anidulafungin & 100 mg/day (day 1: 200 mg) & & & & \\
\hline Micafungin & $100 \mathrm{mg} /$ day & $100 \mathrm{mg} / \mathrm{m}^{2}$ & $\begin{array}{l}>40 \mathrm{~kg}: 100 \mathrm{mg} / \text { day } \\
<40 \mathrm{~kg}: 2-4 \mathrm{mg} / \mathrm{kg} / \text { day }\end{array}$ & $\begin{array}{l}>40 \mathrm{~kg}: 100 \mathrm{mg} / \text { day } \\
<40 \mathrm{~kg}:-4 \mathrm{mg} / \mathrm{kg} / \text { day }\end{array}$ & $\begin{array}{l}>40 \mathrm{~kg}: 100 \mathrm{mg} / \text { day } \\
<40 \mathrm{~kg}:-4 \mathrm{mg} / \mathrm{kg} / \text { day }\end{array}$ \\
\hline
\end{tabular}

QD: once per day; BID: twice per day; QID: four times per day; IV: intravenous; PO: oral; n/a: not sufficient data. * Therapeutic drug monitoring is recommended. Adapted from [111]. 
Data for combination antifungal therapy in children with IFI, including invasive fusariosis, are scant; however, it is frequently used in pediatrics as evidenced by recent pediatric cohort studies $[107,109,118]$. Of note, the association between the receipt of combination therapy and an improved outcome has not been found. The predilection for clinicians to use combination antifungal treatment for invasive fusariosis is probably due to high concern for high or intrinsic resistance of Fusarium spp., the severity of the infection, high mortality-especially in patients with multiple comorbidities requiring salvage treatments-and their uncertainty about the effectiveness and options in treating this serious infection.

A promising approach for the fungal strains that are resistant to currently used antifungal agents or for patients with compromised host immunity is immune based treatments. While, until now, most immunotherapeutic approaches have aimed to augment the number of granulocytes through granulocyte transfusions, the infusion of growth factors (G-CSF, GM-CSF), the administration of cytokines such as IFN- $\gamma$, and most recently, the use of adoptive T cell therapy, which was initiated for the treatment of cancer, seems to be a promising approach for the treatment of patients suffering from drug-resistant IFI [119]. Even though there is growing evidence supporting the role of $\mathrm{T}$ cell adoptive therapy in antifungal immunity, the clinical development of fungus-specific $T$ cells is in the early stages of development, and there is a paucity of data regarding adoptive $\mathrm{T}$ cell therapy using Scedosporium- or Fusarium-specific T cells [120].

In summary, the optimal treatment for scedosporiosis and fusariosis in children is unknown. Voriconazole demonstrates strong in vitro activity against Scedosporium spp and is considered first-line treatment. For fusariosis treatment, voriconazole, lipid formulations of amphotericin B, and various combinations should be considered as the optimal alternatives. Duration of treatment is usually individualized based on the site, the extent of the infection, and the immune status of the patient [63]. In addition, the optimal management should include surgical debridement of infected tissues and reinforcement of immune response either by reducing immunosuppression or augmenting immune response with the use of various growth factors or adoptive $\mathrm{T}$ cell therapies. However, the latter strategy is in its infant state of clinical development with unknown safety and efficacy outcomes.

\section{Conclusions}

Human scedosporiosis and fusariosis are emerging opportunistic infections that are difficult to diagnose and may be even more challenging to treat. In this paper, we have reviewed the challenges associated with diagnosis, which typically relies on labor-intensive histopathology, as well as recent advances in non-culture-based systems. We have also reviewed novel antifungal compounds, such as E1210, F901318, and hemafungin, which may one day play a role in treatment. However, these agents are still in development. For now, treatment of these two potentially-lethal conditions relies on early diagnosis, effective antifungal therapy, possible surgical excision, and reversal of immunosuppression when possible. In the coming years, the mycology community must make it a priority to design non-inferiority trials to evaluate these new agents to meet the needs of vulnerable patients.

Funding: This research received no external funding.

Acknowledgments: All sources of funding of the study have been disclosed.

Conflicts of Interest: The authors declare no conflict of interest.

\section{References}

1. Shaukat, A.; Bakri, F.; Young, P.; Hahn, T.; Ball, D.; Baer, M.R.; Wetzler, M.; Slack, J.L.; Loud, P.; Czuczman, M.; et al. Invasive filamentous fungal infections in allogeneic hematopoietic stem cell transplant recipients after recovery from neutropenia: Clinical, radiologic, and pathologic characteristics. Mycopathologia 2005, 159, 181-188. [CrossRef] [PubMed]

2. Enoch, D.A.; Yang, H.; Aliyu, S.H.; Micallef, C. The Changing Epidemiology of Invasive Fungal Infections. Methods Mol. Biol. 2017, 1508, 17-65. [PubMed] 
3. Mariette, C.; Tavernier, E.; Hocquet, D.; Huynh, A.; Isnard, F.; Legrand, F.; Lhéritier, V.; Raffoux, E.; Dombret, H.; Ifrah, N.; et al. Epidemiology of invasive fungal infections during induction therapy in adults with acute lymphoblastic leukemia: A GRAALL-2005 study. Leuk. Lymphoma 2016, 1-8. [CrossRef] [PubMed]

4. Salehi, E.; Hedayati, M.T.; Zoll, J.; Rafati, H.; Ghasemi, M.; Doroudinia, A.; Abastabar, M.; Tolooe, A.; Snelders, E.; van der Lee, H.A.; et al. Discrimination of aspergillosis, mucormycosis, fusariosis and scedosporiosis in formalin-fixed paraffin-embedded tissue specimens using multiple real-time quantitative PCR assays. J. Clin. Microbiol. 2016. [CrossRef] [PubMed]

5. Park, B.J.; Pappas, P.G.; Wannemuehler, K.A.; Alexander, B.D.; Anaissie, E.J.; Andes, D.R.; Baddley, J.W.; Brown, J.M.; Brumble, L.M.; Freifeld, A.G.; et al. Invasive non-Aspergillus mold infections in transplant recipients, United States, 2001-2006. Emerg. Infect. Dis. 2011, 17, 1855-1864. [CrossRef] [PubMed]

6. Trubiano, J.A.; Paratz, E.; Wolf, M.; Teh, B.W.; Todaro, M.; Thursky, K.A.; Slavin, M.A. Disseminated Scedosporium prolificans infection in an 'extensive metaboliser': Navigating the minefield of drug interactions and pharmacogenomics. Mycoses 2014, 57, 572-576. [CrossRef] [PubMed]

7. Rahman, F.U.; Irfan, M.; Fasih, N.; Jabeen, K.; Sharif, H. Pulmonary scedosporiosis mimicking aspergilloma in an immunocompetent host: A case report and review of the literature. Infection 2016, 44, 127-132. [CrossRef] [PubMed]

8. Matray, O.; Mouhajir, A.; Giraud, S.; Godon, C.; Gargala, G.; Labbé, F.; Rougeron, A.; Ballet, J.J.; Zouhair, R.; Bouchara, J.P.; et al. Semi-automated repetitive sequence-based PCR amplification for species of the Scedosporium apiospermum complex. Med. Mycol. 2016, 54, 409-419. [CrossRef] [PubMed]

9. Lu, Q.; Gerrits van den Ende, A.H.; Bakkers, J.M.; Sun, J.; Lackner, M.; Najafzadeh, M.J.; Melchers, W.J.; Li, R.; de Hoog, G.S. Identification of Pseudallescheria and Scedosporium species by three molecular methods. J. Clin. Microbiol. 2011, 49, 960-967. [CrossRef] [PubMed]

10. Bader, O. Fungal Species Identification by MALDI-ToF Mass Spectrometry. Methods Mol. Biol. 2017, 1508, 323-337. [PubMed]

11. Metzgar, D.; Frinder, M.W.; Rothman, R.E.; Peterson, S.; Carroll, K.C.; Zhang, S.X.; Avornu, G.D.; Rounds, M.A.; Carolan, H.E.; Toleno, D.M.; et al. The IRIDICA BAC BSI Assay: Rapid, Sensitive and Culture-Independent Identification of Bacteria and Candida in Blood. PLoS ONE 2016, 11, e0158186. [CrossRef] [PubMed]

12. McCarthy, M.W.; Walsh, T.J. PCR methodology and applications for the detection of human fungal pathogens. Expert Rev. Mol. Diagn. 2016, 16, 1025-1036. [CrossRef] [PubMed]

13. Massire, C.; Buelow, D.R.; Zhang, S.X.; Lovari, R.; Matthews, H.E.; Toleno, D.M.; Ranken, R.R.; Hall, T.A.; Metzgar, D.; Sampath, R.; et al. PCR followed by electrospray ionization mass spectrometry for broad-range identification of fungal pathogens. J. Clin. Microbiol. 2013, 51, 959-966. [CrossRef] [PubMed]

14. Yonetani, S.; Ohnishi, H.; Ohkusu, K.; Matsumoto, T.; Watanabe, T. Direct identification of microorganisms from positive blood cultures by MALDI-TOF MS using an in-house saponin method. Int. J. Infect. Dis. 2016, 52, 37-42. [CrossRef] [PubMed]

15. Ye, H.; Wang, J.; Greer, T.; Strupat, K.; Li, L. Visualizing neurotransmitters and metabolites in the central nervous system by high resolution and high accuracy mass spectrometric imaging. ACS Chem. Neurosci. 2013, 4, 1049-1056. [CrossRef] [PubMed]

16. Yaman, G.; Akyar, I.; Can, S. Evaluation of the MALDI TOF-MS method for identification of Candida strains isolated from blood cultures. Diagn. Microbiol. Infect. Dis. 2012, 73, 65-67. [CrossRef] [PubMed]

17. Montejo, M.; Muñiz, M.L.; Zárraga, S.; Aguirrebengoa, K.; Amenabar, J.J.; López-Soria, L.; Gonzalez, R. Case Reports. Infection due to Scedosporium apiospermum in renal transplant recipients: A report of two cases and literature review of central nervous system and cutaneous infections by Pseudallescheria boydii/Sc. apiospermum. Mycoses 2002, 45, 418-427. [CrossRef] [PubMed]

18. Muñoz, P.; Singh, N.; Bouza, E. Treatment of solid organ transplant patients with invasive fungal infections: Should a combination of antifungal drugs be used? Curr. Opin. Infect. Dis. 2006, 19, 365-370. [CrossRef] [PubMed]

19. McCarthy, M.; Rosengart, A.; Schuetz, A.N.; Kontoyiannis, D.P.; Walsh, T.J. Mold infections of the central nervous system. N. Engl. J. Med. 2014, 371, 150-160. [CrossRef] [PubMed]

20. Gruber, M.; Moser, I.; Nagl, M.; Lackner, M. Bactericidal and fungicidal activity of N-chlorotaurine is enhanced in cystic fibrosis sputum medium. Antimicrob. Agents Chemother. 2017. [CrossRef] [PubMed] 
21. Han, Z.; Kautto, L.; Nevalainen, H. Secretion of Proteases by an Opportunistic Fungal Pathogen Scedosporium aurantiacum. PLoS ONE 2017, 12, e0169403. [CrossRef] [PubMed]

22. Debono, M.; Gordee, R.S. Antibiotics that inhibit fungal cell wall development. Annu. Rev. Microbiol. 1994, 48, 471-497. [CrossRef] [PubMed]

23. Espinel-Ingroff, A. Comparison of In vitro activities of the new triazole SCH56592 and the echinocandins MK-0991 (L-743,872) and LY303366 against opportunistic filamentous and dimorphic fungi and yeasts. J. Clin. Microbiol. 1998, 36, 2950-2956. [PubMed]

24. Guinea, J.; Bouza, E. Isavuconazole: A new and promising antifungal triazole for the treatment of invasive fungal infections. Future Microbiol. 2008, 3, 603-615. [CrossRef] [PubMed]

25. Emminger, W.; Graninger, W.; Emminger-Schmidmeier, W.; Zoubek, A.; Pillwein, K.; Susani, M.; Wasserer, A.; Gadner, H. Tolerance of high doses of amphotericin B by infusion of a liposomal formulation in children with cancer. Ann. Hematol. 1994, 68, 27-31. [CrossRef] [PubMed]

26. Park, S.C.; Kim, Y.M.; Lee, J.K.; Kim, N.H.; Kim, E.J.; Heo, H.; Lee, M.Y.; Lee, J.R.; Jang, M.K. Targeting and synergistic action of an antifungal peptide in an antibiotic drug-delivery system. J. Control. Release 2017. [CrossRef] [PubMed]

27. Seyedmousavi, S.; Rafati, H.; Ilkit, M.; Tolooe, A.; Hedayati, M.T.; Verweij, P. Systemic Antifungal Agents: Current Status and Projected Future Developments. Methods Mol. Biol. 2017, 1508, 107-139. [PubMed]

28. Arendrup, M.C. Update on antifungal resistance in Aspergillus and Candida. Clin. Microbiol. Infect. 2014, 20 (Suppl. S6), 42-48. [CrossRef] [PubMed]

29. Troke, P.; Aguirrebengoa, K.; Arteaga, C.; Ellis, D.; Heath, C.H.; Lutsar, I.; Rovira, M.; Nguyen, Q.; Slavin, M.; Chen, S.C.; et al. Treatment of scedosporiosis with voriconazole: Clinical experience with 107 patients. Antimicrob. Agents Chemother. 2008, 52, 1743-1750. [CrossRef] [PubMed]

30. Lackner, M.; Hagen, F.; Meis, J.F.; Gerrits van den Ende, A.H.; Vu, D.; Robert, V.; Fritz, J.; Moussa, T.A.; de Hoog, G.S. Susceptibility and diversity in the therapy-refractory genus Scedosporium. Antimicrob. Agents Chemother. 2014, 58, 5877-5885. [CrossRef] [PubMed]

31. Steinbach, W.J.; Schell, W.A.; Miller, J.L.; Perfect, J.R. Scedosporium prolificans osteomyelitis in an immunocompetent child treated with voriconazole and caspofungin, as well as locally applied polyhexamethylene biguanide. J. Clin. Microbiol. 2003, 41, 3981-3985. [CrossRef] [PubMed]

32. Pasqualotto, A.C.; Thiele, K.O.; Goldani, L.Z. Novel triazole antifungal drugs: Focus on isavuconazole, ravuconazole and albaconazole. Curr. Opin. Investig. Drugs 2010, 11, 165-174. [PubMed]

33. Perfect, J.R.; Marr, K.A.; Walsh, T.J.; Greenberg, R.N.; DuPont, B.; de la Torre-Cisneros, J.; Just-Nübling, G.; Schlamm, H.T.; Lutsar, I.; Espinel-Ingroff, A.; et al. Voriconazole treatment for less-common, emerging, or refractory fungal infections. Clin. Infect. Dis. 2003, 36, 1122-1131. [CrossRef] [PubMed]

34. Holmes, N.E.; Trevillyan, J.M.; Kidd, S.E.; Leong, T.Y. Locally extensive angio-invasive Scedosporium prolificans infection following resection for squamous cell lung carcinoma. Med. Mycol. Case Rep. 2013, 2, 98-102. [CrossRef] [PubMed]

35. Kim, S.H.; Ha, Y.E.; Youn, J.C.; Park, J.S.; Sung, H.; Kim, M.N.; Choi, H.J.; Lee, Y.J.; Kang, S.M.; Ahn, J.Y.; et al. Fatal scedosporiosis in multiple solid organ allografts transmitted from a nearly-drowned donor. Am. J. Transplant. 2015, 15, 833-840. [CrossRef] [PubMed]

36. Taylor, A.; Talbot, J.; Bennett, P.; Martin, P.; Makara, M.; Barrs, V.R. Disseminated Scedosporium prolificans infection in a Labrador retriever with immune mediated haemolytic anaemia. Med. Mycol. Case Rep. 2014, 6, 66-69. [CrossRef] [PubMed]

37. Kesson, A.M.; Bellemore, M.C.; O’Mara, T.J.; Ellis, D.H.; Sorrell, T.C. Scedosporium prolificans osteomyelitis in an immunocompetent child treated with a novel agent, hexadecylphospocholine (miltefosine), in combination with terbinafine and voriconazole: A case report. Clin. Infect. Dis. 2009, 48, 1257-1261. [CrossRef] [PubMed]

38. Lepak, A.J.; Marchillo, K.; VanHecker, J.; Diekema, D.; Andes, D.R. Isavuconazole pharmacodynamic target determination for Candida species in an in vivo murine disseminated candidiasis model. Antimicrob. Agents Chemother. 2013, 57, 5642-5648. [CrossRef] [PubMed]

39. Wiederhold, N.P.; Kovanda, L.; Najvar, L.K.; Bocanegra, R.; Olivo, M.; Kirkpatrick, W.R.; Patterson, T.F. Isavuconazole Is Effective for the Treatment of Experimental Cryptococcal Meningitis. Antimicrob. Agents Chemother. 2016, 60, 5600-5603. [CrossRef] [PubMed] 
40. Kovanda, L.L.; Kolamunnage-Dona, R.; Neely, M.; Maertens, J.; Lee, M.; Hope, W.W. Pharmacodynamics of Isavuconazole for Invasive Mold Disease: Role of Galactomannan for Real-Time Monitoring of Therapeutic Response. Clin. Infect. Dis. 2017, 64, 1557-1563. [CrossRef] [PubMed]

41. Box, H.; Livermore, J.; Johnson, A.; McEntee, L.; Felton, T.W.; Whalley, S.; Goodwin, J.; Hope, W.W. Pharmacodynamics of Isavuconazole in a Dynamic In Vitro Model of Invasive Pulmonary Aspergillosis. Antimicrob. Agents Chemother. 2015, 60, 278-287. [CrossRef] [PubMed]

42. McCarthy, M.W.; Moriyama, B.; Petraitiene, R.; Walsh, T.J.; Petraitis, V. Clinical Pharmacokinetics and Pharmacodynamics of Isavuconazole. Clin. Pharmacokinet. 2018. [CrossRef] [PubMed]

43. Guinea, J.; Hagen, F.; Peláez, T.; Boekhout, T.; Tahoune, H.; Torres-Narbona, M.; Bouza, E. Antifungal susceptibility, serotyping, and genotyping of clinical Cryptococcus neoformans isolates collected during 18 years in a single institution in Madrid, Spain. Med. Mycol. 2010, 48, 942-948. [CrossRef] [PubMed]

44. Pfaller, M.A.; Messer, S.A.; Rhomberg, P.R.; Jones, R.N.; Castanheira, M. In vitro activities of isavuconazole and comparator antifungal agents tested against a global collection of opportunistic yeasts and molds. J. Clin. Microbiol. 2013, 51, 2608-2616. [CrossRef] [PubMed]

45. Oliver, J.D.; Sibley, G.E.; Beckmann, N.; Dobb, K.S.; Slater, M.J.; McEntee, L.; du Pré, S.; Livermore, J.; Bromley, M.J.; Wiederhold, N.P.; et al. F901318 represents a novel class of antifungal drug that inhibits dihydroorotate dehydrogenase. Proc. Natl. Acad. Sci. USA 2016. [CrossRef] [PubMed]

46. Wiederhold, N.P.; Law, D.; Birch, M. Dihydroorotate dehydrogenase inhibitor F901318 has potent in vitro activity against Scedosporium species and Lomentospora prolificans. J. Antimicrob. Chemother. 2017, 72, 1977-1980. [CrossRef] [PubMed]

47. Walsh, T.J.; Chanock, S.J. Diagnosis of invasive fungal infections: Advances in nonculture systems. Curr. Clin. Top. Infect. Dis. 1998, 18, 101-153. [PubMed]

48. Van Diepeningen, A.D.; Brankovics, B.; Iltes, J.; van der Lee, T.A.; Waalwijk, C. Diagnosis of Fusarium Infections: Approaches to Identification by the Clinical Mycology Laboratory. Curr. Fungal Infect. Rep. 2015, 9, 135-143. [CrossRef] [PubMed]

49. Jurado, M.; Vázquez, C.; Patiño, B.; González-Jaén, M.T. PCR detection assays for the trichothecene-producing species Fusarium graminearum, Fusarium culmorum, Fusarium poae, Fusarium equiseti and Fusarium sporotrichioides. Syst. Appl. Microbiol. 2005, 28, 562-568. [CrossRef] [PubMed]

50. Healy, M.; Reece, K.; Walton, D.; Huong, J.; Frye, S.; Raad, I.I.; Kontoyiannis, D.P. Use of the Diversi Lab System for species and strain differentiation of Fusarium species isolates. J. Clin. Microbiol. 2005, 43, 5278-5280. [CrossRef] [PubMed]

51. He, Y.; Ahmad, D.; Zhang, X.; Zhang, Y.; Wu, L.; Jiang, P.; Ma, H. Genome-wide analysis of family-1 UDP glycosyltransferases (UGT) and identification of UGT genes for FHB resistance in wheat (Triticum aestivum L.). BMC Plant Biol. 2018, 18, 67. [CrossRef] [PubMed]

52. Hata, D.J.; Buckwalter, S.P.; Pritt, B.S.; Roberts, G.D.; Wengenack, N.L. Real-time PCR method for detection of zygomycetes. J. Clin. Microbiol. 2008, 46, 2353-2358. [CrossRef] [PubMed]

53. Manikandan, R.; Harish, S.; Karthikeyan, G.; Raguchander, T. Comparative Proteomic Analysis of Different Isolates of Fusarium oxysporum f.sp. lycopersici to Exploit the Differentially Expressed Proteins Responsible for Virulence on Tomato Plants. Front. Microbiol. 2018, 9, 420. [CrossRef] [PubMed]

54. Diao, X.; Han, Y.; Liu, C. The Fungicidal Activity of Tebuconazole Enantiomers against Fusarium graminearum and Its Selective Effect on DON Production under Different Conditions. J. Agric. Food Chem. 2018, 66, 3637-3643. [CrossRef] [PubMed]

55. Van Diepeningen, A.D.; Feng, P.; Ahmed, S.; Sudhadham, M.; Bunyaratavej, S.; de Hoog, G.S. Spectrum of Fusarium infections in tropical dermatology evidenced by multilocus sequencing typing diagnostics. Mycoses 2015, 58, 48-57. [CrossRef] [PubMed]

56. Becker, P.T.; de Bel, A.; Martiny, D.; Ranque, S.; Piarroux, R.; Cassagne, C.; Detandt, M.; Hendrickx, M. Identification of filamentous fungi isolates by MALDI-TOF mass spectrometry: Clinical evaluation of an extended reference spectra library. Med. Mycol. 2014, 52, 826-834. [CrossRef] [PubMed]

57. Hanrieder, J.; Wicher, G.; Bergquist, J.; Andersson, M.; Fex-Svenningsen, A. MALDI mass spectrometry based molecular phenotyping of CNS glial cells for prediction in mammalian brain tissue. Anal. Bioanal. Chem. 2011, 401, 135-147. [CrossRef] [PubMed]

58. Lay, J.O. MALDI-TOF mass spectrometry of bacteria. Mass. Spectrom. Rev. 2001, 20, 172-194. [CrossRef] [PubMed] 
59. Steinberg, G.K.; Britt, R.H.; Enzmann, D.R.; Finlay, J.L.; Arvin, A.M. Fusarium brain abscess. Case report. J. Neurosurg. 1983, 58, 598-601. [CrossRef] [PubMed]

60. Dignani, M.C.; Anaissie, E. Human fusariosis. Clin. Microbiol. Infect. 2004, 10 (Suppl. S1), 67-75. [CrossRef] [PubMed]

61. Anaissie, E.; Paetznick, V.; Proffitt, R.; Adler-Moore, J.; Bodey, G.P. Comparison of the in vitro antifungal activity of free and liposome-encapsulated amphotericin B. Eur. J. Clin. Microbiol. Infect. Dis. 1991, 10, 665-668. [CrossRef] [PubMed]

62. Martino, P.; Gastaldi, R.; Raccah, R.; Girmenia, C. Clinical patterns of Fusarium infections in immunocompromised patients. J. Infect. 1994, 28 (Suppl. S1), 7-15. [CrossRef]

63. Nucci, F.; Nouér, S.A.; Capone, D.; Anaissie, E.; Nucci, M. Fusariosis. Semin. Respir. Crit. Care Med. 2015, 36, 706-714. [CrossRef] [PubMed]

64. Rabodonirina, M.; Piens, M.A.; Monier, M.F.; Guého, E.; Fière, D.; Mojon, M. Fusarium infections in immunocompromised patients: Case reports and literature review. Eur. J. Clin. Microbiol. Infect. Dis. 1994, 13, 152-161. [CrossRef] [PubMed]

65. Walsh, T.J.; Hiemenz, J.W.; Anaissie, E. Recent progress and current problems in treatment of invasive fungal infections in neutropenic patients. Infect. Dis. Clin. N. Am. 1996, 10, 365-400. [CrossRef]

66. Chan, T.S.; Au-Yeung, R.; Chim, C.S.; Wong, S.C.; Kwong, Y.L. Disseminated fusarium infection after ibrutinib therapy in chronic lymphocytic leukaemia. Ann. Hematol. 2017, 96, 871-872. [CrossRef] [PubMed]

67. Farrag, R.M. Intracellular Siderophore Detection in an Egyptian, Cobalt-Treated F. solani Isolate Using SEM-EDX with Reference to its Tolerance. Pol. J. Microbiol. 2017, 66, 235-243. [PubMed]

68. Arnoni, M.V.; Paula, C.R.; Auler, M.E.; Simões, C.C.N.; Nakano, S.; Szeszs, M.W.; Melhem, M.S.C.; Pereira, V.B.R.; Garces, H.G.; Bagagli, E.; et al. Infections Caused by Fusarium Species in Pediatric Cancer Patients and Review of Published Literature. Mycopathologia 2018. [CrossRef] [PubMed]

69. Tupaki-Sreepurna, A.; Thanneru, V.; Natarajan, S.; Sharma, S.; Gopi, A.; Sundaram, M.; Kindo, A.J. Phylogenetic Diversity and In Vitro Susceptibility Profiles of Human Pathogenic Members of the Fusarium fujikuroi Species Complex Isolated from South India. Mycopathologia 2018. [CrossRef] [PubMed]

70. McCarthy, M.W.; Kontoyiannis, D.P.; Cornely, O.A.; Perfect, J.R.; Walsh, T.J. Novel Agents and Drug Targets to Meet the Challenges of Resistant Fungi. J. Infect. Dis 2017, 216, S474-S483. [CrossRef] [PubMed]

71. Wiederhold, N.P.; Najvar, L.K.; Fothergill, A.W.; McCarthy, D.I.; Bocanegra, R.; Olivo, M.; Kirkpatrick, W.R.; Everson, M.P.; Duncanson, F.P.; Patterson, T.F. The investigational agent E1210 is effective in treatment of experimental invasive candidiasis caused by resistant Candida albicans. Antimicrob. Agents Chemother. 2015, 59, 690-692. [CrossRef] [PubMed]

72. Watanabe, N.A.; Miyazaki, M.; Horii, T.; Sagane, K.; Tsukahara, K.; Hata, K. E1210, a new broad-spectrum antifungal, suppresses Candida albicans hyphal growth through inhibition of glycosylphosphatidylinositol biosynthesis. Antimicrob. Agents Chemother. 2012, 56, 960-971. [CrossRef] [PubMed]

73. Pfaller, M.A.; Watanabe, N.; Castanheira, M.; Messer, S.A.; Jones, R.N. Pre-clinical development of antifungal susceptibility test methods for the testing of the novel antifungal agent E1210 versus Candida: Comparison of CLSI and European Committee on Antimicrobial Susceptibility Testing methods. J. Antimicrob. Chemother. 2011, 66, 2581-2584. [CrossRef] [PubMed]

74. McCarthy, M.W.; Denning, D.W.; Walsh, T.J. Future Research Priorities in Fungal Resistance. J. Infect. Dis. 2017, 216, S484-S492. [CrossRef] [PubMed]

75. Romani, L. Immunity to fungal infections. Nat. Rev. Immunol. 2011, 11, 275-288. [CrossRef] [PubMed]

76. Gil-Lamaignere, C.; Roilides, E.; Lyman, C.A.; Simitsopoulou, M.; Stergiopoulou, T.; Maloukou, A.; Walsh, T.J. Human phagocytic cell responses to Scedosporium apiospermum (Pseudallescheria boydii): Variable susceptibility to oxidative injury. Infect. Immun. 2003, 71, 6472-6478. [CrossRef] [PubMed]

77. Gil-Lamaignere, C.; Maloukou, A.; Rodriguez-Tudela, J.L.; Roilides, E. Human phagocytic cell responses to Scedosporium prolificans. Med. Mycol. 2001, 39, 169-175. [CrossRef] [PubMed]

78. Becker, K.L.; Ifrim, D.C.; Quintin, J.; Netea, M.G.; van de Veerdonk, F.L. Antifungal innate immunity: Recognition and inflammatory networks. Semin. Immunopathol. 2015, 37, 107-116. [CrossRef] [PubMed]

79. Armstrong-James, D.; Brown, G.D.; Netea, M.G.; Zelante, T.; Gresnigt, M.S.; van de Veerdonk, F.L.; Levitz, S.M. Immunotherapeutic approaches to treatment of fungal diseases. Lancet Inf. Dis. 2017, 17, e393-e402. [CrossRef] 
80. Warris, A.; Netea, M.G.; Verweij, P.E.; Gaustad, P.; Kullberg, B.J.; Weemaes, C.M.; Abrahamsen, T.G. Cytokine responses and regulation of interferon-gamma release by human mononuclear cells to Aspergillus fumigatus and other filamentous fungi. Med. Mycol. 2005, 43, 613-621. [CrossRef] [PubMed]

81. Winn, R.M.; Gil-Lamaignere, C.; Roilides, E.; Simitsopoulou, M.; Lyman, C.A.; Maloukou, A.; Walsh, T.J. Effects of interleukin-15 on antifungal responses of human polymorphonuclear leukocytes against Fusarium spp. and Scedosporium spp. Cytokine 2005, 31, 1-8. [CrossRef] [PubMed]

82. Gil-Lamaignere, C.; Winn, R.M.; Simitsopoulou, M.; Maloukou, A.; Walsh, T.J.; Roilides, E. Inteferon gamma and granulocyte-macrophage colony-stimulating factor augment the antifungal activity of human polymorphonuclear leukocytes against Scedosporium spp.: Comparison with Aspergillus spp. Med. Mycol. 2005, 43, 253-260. [CrossRef] [PubMed]

83. Cassatella, M.A.; Bazzoni, F.; Flynn, R.M.; Dusi, S.; Trinchieri, G.; Rossi, F. Molecular basis of interferon-gamma and lipopolysaccharide enhancement of phagocyte respiratory burst capability. Studies on the gene expression of several NADPH oxidase components. J. Biol. Chem. 1990, 265, 20241-20246. [PubMed]

84. Rodriguez-Adrian, L.J.; Grazziutti, M.L.; Rex, J.H.; Anaissie, E.J. The potential role of cytokine therapy for fungal infections in patients with cancer: Is recovery from neutropenia all that is needed? Clin. Infect. Dis. 1998, 26, 1270-1278. [CrossRef] [PubMed]

85. Armitage, J.O. Emerging applications of recombinant human granulocyte-macrophage colony-stimulating factor. Blood 1998, 92, 4491-4508. [PubMed]

86. Roilides, E.; Lyman, C.A.; Armstrong, D.; Stergiopoulou, T.; Petraitiene, R.; Walsh, T.J. Deoxycholate amphotericin B and amphotericin B lipid complex exert additive antifungal activity in combination with pulmonary alveolar macrophages against Fusarium solani. Mycoses 2006, 49, 109-113. [CrossRef] [PubMed]

87. Dotis, J.; Simitsopoulou, M.; Dalakiouridou, M.; Konstantinou, T.; Panteliadis, C.; Walsh, T.J.; Roilides, E. Amphotericin B formulations variably enhance antifungal activity of human neutrophils and monocytes against Fusarium solani: Comparison with Aspergillus fumigatus. J. Antimicrob. Chemother. 2008, 61, 810-817. [CrossRef] [PubMed]

88. Gil-Lamaignere, C.; Roilides, E.; Maloukou, A.; Georgopoulou, I.; Petrikkos, G.; Walsh, T.J. Amphotericin B lipid complex exerts additive antifungal activity in combination with polymorphonuclear leucocytes against Scedosporium prolificans and Scedosporium apiospermum. J. Antimicrob. Chemother. 2002, 50, 1027-1030. [CrossRef] [PubMed]

89. Gil-Lamaignere, C.; Roilides, E.; Mosquera, J.; Maloukou, A.; Walsh, T.J. Antifungal triazoles and polymorphonuclear leukocytes synergize to cause increased hyphal damage to Scedosporium prolificans and Scedosporium apiospermum. Antimicrob. Agents Chemother. 2002, 46, 2234-2237. [CrossRef] [PubMed]

90. Ortoneda, M.; Capilla, J.; Pujol, I.; Pastor, F.J.; Mayayo, E.; Fernandez-Ballart, J.; Guarro, J. Liposomal amphotericin B and granulocyte colony-stimulating factor therapy in a murine model of invasive infection by Scedosporium prolificans. J. Antimicrob. Chemother. 2002, 49, 525-529. [CrossRef] [PubMed]

91. Ortoneda, M.; Capilla, J.; Pastor, F.J.; Serena, C.; Guarro, J. Interaction of granulocyte colony-stimulating factor and high doses of liposomal amphotericin B in the treatment of systemic murine scedosporiosis. Diagn. Microbiol. Infect. Dis. 2004, 50, 247-251. [CrossRef] [PubMed]

92. Simitsopoulou, M.; Gil-Lamaignere, C.; Avramidis, N.; Maloukou, A.; Lekkas, S.; Havlova, E.; Kourounaki, L.; Loebenberg, D.; Roilides, E. Antifungal activities of posaconazole and granulocyte-macrophage colony-stimulating factor ex vivo and in mice with disseminated infection due to Scedosporium prolificans. Antimicrob. Agents Chemother. 2004, 48, 3801-3805. [CrossRef] [PubMed]

93. Dignani, M.C.; Anaissie, E.J.; Hester, J.P.; O’Brien, S.; Vartivarian, S.E.; Rex, J.H.; Kantarjian, H.; Jendiroba, D.B.; Lichtiger, B.; Andersson, B.S.; et al. Treatment of neutropenia-related fungal infections with granulocyte colony-stimulating factor-elicited white blood cell transfusions: A pilot study. Leukemia 1997, 11, 1621-1630. [CrossRef] [PubMed]

94. Boutati, E.I.; Anaissie, E.J. Fusarium, a significant emerging pathogen in patients with hematologic malignancy: Ten years' experience at a cancer center and implications for management. Blood 1997, 90, 999-1008. [PubMed]

95. Price, T.H.; Bowden, R.A.; Boeckh, M.; Bux, J.; Nelson, K.; Liles, W.C.; Dale, D.C. Phase I/II trial of neutrophil transfusions from donors stimulated with G-CSF and dexamethasone for treatment of patients with infections in hematopoietic stem cell transplantation. Blood 2000, 95, 3302-3309. [PubMed] 
96. Rutella, S.; Pierelli, L.; Sica, S.; Serafini, R.; Chiusolo, P.; Paladini, U.; Leone, F.; Zini, G.; D'Onofrio, G.; Leone, G.; et al. Efficacy of granulocyte transfusions for neutropenia-related infections: Retrospective analysis of predictive factors. Cytotherapy 2003, 5, 19-30. [CrossRef] [PubMed]

97. Kadri, S.S.; Remy, K.E.; Strich, J.R.; Gea-Banacloche, J.; Leitman, S.F. Role of granulocyte transfusions in invasive fusariosis: Systematic review and single-center experience. Transfusion 2015, 55, 2076-2085. [CrossRef] [PubMed]

98. Yoshihara, S.; Ikemoto, J.; Fujimori, Y. Update on granulocyte transfusions: Accumulation of promising data, but still lack of decisive evidence. Curr. Opin. Hematol. 2016, 23, 55-60. [CrossRef] [PubMed]

99. Goldman, C.; Akiyama, M.J.; Torres, J.; Louie, E.; Meehan, S.A. Scedosporium apiospermum infections and the role of combination antifungal therapy and GM-CSF: A case report and review of the literature. Med. Mycol. Case Rep. 2016, 11, 40-43. [CrossRef] [PubMed]

100. Guarro, J.; Kantarcioglu, A.S.; Horre, R.; Luis Rodriguez-Tudela, J.; Cuenca Estrella, M.; Berenguer, J.; Sybren De Hoog, G. Scedosporium apiospermum: Changing clinical spectrum of a therapy-refractory opportunist. Med. Mycol. 2006, 44, 295-327. [CrossRef] [PubMed]

101. Munoz, P.; Marin, M.; Tornero, P.; Martin Rabadan, P.; Rodriguez-Creixems, M.; Bouza, E. Successful outcome of Scedosporium apiospermum disseminated infection treated with voriconazole in a patient receiving corticosteroid therapy. Clin. Infect. Dis. 2000, 31, 1499-1501. [CrossRef] [PubMed]

102. Phillips, P.; Forbes, J.C.; Speert, D.P. Disseminated infection with Pseudallescheria boydii in a patient with chronic granulomatous disease: Response to gamma-interferon plus antifungal chemotherapy. Pediatr. Infect. Dis. J. 1991, 10, 536-539. [CrossRef] [PubMed]

103. Berenguer, J.; Rodriguez-Tudela, J.L.; Richard, C.; Alvarez, M.; Sanz, M.A.; Gaztelurrutia, L.; Ayats, J.; Martinez-Suarez, J.V. Deep infections caused by Scedosporium prolificans. A report on 16 cases in Spain and a review of the literature. Scedosporium Prolificans Spanish Study Group. Medicine 1997, 76, 256-265. [CrossRef] [PubMed]

104. Revankar, S.G.; Patterson, J.E.; Sutton, D.A.; Pullen, R.; Rinaldi, M.G. Disseminated phaeohyphomycosis: Review of an emerging mycosis. Clin. Infect. Dis. 2002, 34, 467-476. [CrossRef] [PubMed]

105. Cortez, K.J.; Roilides, E.; Quiroz-Telles, F.; Meletiadis, J.; Antachopoulos, C.; Knudsen, T.; Buchanan, W.; Milanovich, J.; Sutton, D.A.; Fothergill, A.; et al. Infections caused by Scedosporium spp. Clin. Microbiol. Rev. 2008, 21, 157-197. [CrossRef] [PubMed]

106. Mursch, K.; Trnovec, S.; Ratz, H.; Hammer, D.; Horre, R.; Klinghammer, A.; de Hoog, S.; Behnke-Mursch, J. Successful treatment of multiple Pseudallescheria boydii brain abscesses and ventriculitis/ependymitis in a 2-year-old child after a near-drowning episode. Childs Nerv. Syst. 2006, 22, 189-192. [PubMed]

107. Wattier, R.L.; Dvorak, C.C.; Hoffman, J.A.; Brozovich, A.A.; Bin-Hussain, I.; Groll, A.H.; Castagnola, E.; Knapp, K.M.; Zaoutis, T.E.; Gustafsson, B.; et al. A Prospective, International Cohort Study of Invasive Mold Infections in Children. J. Pediatric Infect. Dis. Soc. 2015, 4, 313-322. [CrossRef] [PubMed]

108. Schwartz, K.L.; Sheffield, H.; Richardson, S.E.; Sung, L.; Morris, S.K. Invasive Fusariosis: A Single Pediatric Center 15-Year Experience. J. Pediatric Infect. Dis. Soc. 2015, 4, 163-170. [CrossRef] [PubMed]

109. Georgiadou, S.P.; Pongas, G.; Fitzgerald, N.E.; Lewis, R.E.; Rytting, M.; Marom, E.M.; Kontoyiannis, D.P. Invasive Mold Infections in Pediatric Cancer Patients Reflect Heterogeneity in Etiology, Presentation, and Outcome: A 10-Year, Single-Institution, Retrospective Study. J. Pediatric Infect. Dis. Soc. 2012, 1, 125-135. [CrossRef] [PubMed]

110. Nucci, M.; Marr, K.A.; Queiroz-Telles, F.; Martins, C.A.; Trabasso, P.; Costa, S.; Voltarelli, J.C.; Colombo, A.L.; Imhof, A.; Pasquini, R.; et al. Fusarium infection in hematopoietic stem cell transplant recipients. Clin. Infect. Dis. 2004, 38, 1237-1242. [CrossRef] [PubMed]

111. Tortorano, A.M.; Richardson, M.; Roilides, E.; van Diepeningen, A.; Caira, M.; Munoz, P.; Johnson, E.; Meletiadis, J.; Pana, Z.D.; Lackner, M.; et al. ESCMID and ECMM joint guidelines on diagnosis and management of hyalohyphomycosis: Fusarium spp., Scedosporium spp. and others. Clin. Microbiol. Infect. 2014, 20 (Suppl. S3), 27-46. [CrossRef] [PubMed]

112. Hassler, A.; Lieb, A.; Seidel, D.; Cesaro, S.; Greil, J.; Klimko, N.; Khostelidi, S.; Solopova, G.; Ogunc, D.; Duran Graeff, L.; et al. Disseminated Fusariosis in Immunocompromised Children-Analysis of Recent Cases Identified in the Global Fungiscope Registry. Pediatr. Infect. Dis. J. 2017, 36, 230-231. [CrossRef] [PubMed]

113. Ledoux, M.P.; Denis, J.; Nivoix, Y.; Herbrecht, R. Isavuconazole: A new broad-spectrum azole. Part 2: Pharmacokinetics and clinical activity. J. Mycol. Med. 2018. [CrossRef] [PubMed] 
114. Raad, I.I.; Hachem, R.Y.; Herbrecht, R.; Graybill, J.R.; Hare, R.; Corcoran, G.; Kontoyiannis, D.P. Posaconazole as salvage treatment for invasive fusariosis in patients with underlying hematologic malignancy and other conditions. Clin. Infect. Dis. 2006, 42, 1398-1403. [CrossRef] [PubMed]

115. Campo, M.; Lewis, R.E.; Kontoyiannis, D.P. Invasive fusariosis in patients with hematologic malignancies at a cancer center: 1998-2009. J. Infect. 2010, 60, 331-337. [CrossRef] [PubMed]

116. Cornely, O.A.; Mullane, K.M.; Ostrosky-Zeichner, L.; Maher, R.M.; Croos-Dabrera, R.; Lu, Q.; Lademacher, C.; Perfect, J.R.; Oren, I.; Schmitt-Hoffmann, A.H.; et al. Isavuconazole for treatment of rare invasive fungal diseases. Mycoses 2018. [CrossRef] [PubMed]

117. Al-Hatmi, A.M.S.; Bonifaz, A.; Ranque, S.; Sybren de Hoog, G.; Verweij, P.E.; Meis, J.F. Current antifungal treatment of fusariosis. Int. J. Antimicrob. Agents 2018, 51, 326-332. [CrossRef] [PubMed]

118. Burgos, A.; Zaoutis, T.E.; Dvorak, C.C.; Hoffman, J.A.; Knapp, K.M.; Nania, J.J.; Prasad, P.; Steinbach, W.J. Pediatric invasive aspergillosis: A multicenter retrospective analysis of 139 contemporary cases. Pediatrics 2008, 121, e1286-e1294. [CrossRef] [PubMed]

119. Kumaresan, P.R.; Manuri, P.R.; Albert, N.D.; Maiti, S.; Singh, H.; Mi, T.; Roszik, J.; Rabinovich, B.; Olivares, S.; Krishnamurthy, J.; et al. Bioengineering T cells to target carbohydrate to treat opportunistic fungal infection. Proc. Natl. Acad. Sci. USA 2014, 111, 10660-10665. [CrossRef] [PubMed]

120. Fuji, S.; Loffler, J.; Einsele, H.; Kapp, M. Immunotherapy for opportunistic infections: Current status and future perspectives. Virulence 2016, 7, 939-949. [CrossRef] [PubMed]

(C) 2018 by the authors. Licensee MDPI, Basel, Switzerland. This article is an open access article distributed under the terms and conditions of the Creative Commons Attribution (CC BY) license (http://creativecommons.org/licenses/by/4.0/). 